\title{
Elevated concentrations of gaseous elemental mercury in air and surface soil in the historical silver mining region, Guanajuato, Mexico
}

\author{
A. LORIA ${ }^{1 *}$, Y. R. RAMOS-ARROYO ${ }^{2}$, D. ROCHA ${ }^{2}, \mathrm{G}$. \\ CRUZ-JIMÉNEZ ${ }^{2}$, I. RAZO SOTO ${ }^{3}$, C. ALFARO DE LA

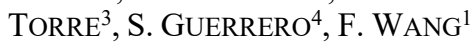 \\ ${ }^{1}$ University of Manitoba, Winnipeg, MB R3T 2N2, Canada \\ (*correspondance: loriaa@myumanitoba.ca) \\ ${ }^{2}$ UGTO, Guanajuato, GTO 36000, México \\ ${ }^{3}$ UASLP, San Luis Potosí, SLP 78210, México \\ ${ }^{4}$ Caracas, Venezuela
}

Recent advancements in our understanding of silver amalgamation, otherwise known as the patio process, suggest that the amounts of mercury emitted into the atmosphere during silver mining processes of the Spanish Colonial Era have been overestimated. In past estimates, it was assumed that most of the mercury used in this process was lost through volatilization, but we now know that a significant amount of mercury (an estimated 64 to $90 \%$ ) was chemically converted to calomel $\left(\mathrm{Hg}_{2} \mathrm{Cl}_{2}\right)$. The behaviour of calomel in the environment is not well known, although it is thought to undergo a disproportionation reaction forming gaseous elemental mercury (GEM) and mercuric chloride $\left(\mathrm{HgCl}_{2}\right)$. As such, the aim of this study was to locate mercury waste 'hotspots' using a portable GEM analyzer in and around historical tailing and sediment sites in the city of Guanajuato, Mexico, where mercury was used extensively to extract silver from 1556 until 1905. Our results show mean surface GEM levels at tailing, sediment and 'other' sites to be $126 \mathrm{ng} \mathrm{m}^{-3}$, $55 \mathrm{ng} \mathrm{m}^{-3}$ and $50 \mathrm{ng} \mathrm{m}^{-3}$, respectively, with the maximum value being as high as $44,705 \mathrm{ng} \mathrm{m}^{-3}$. In general, GEM releases from tailings and sediments are elevated, but are short-lived, localized and seemingly only occur upon disturbance. At most sites exposure is limited, so high incidences of GEM are not likely to pose an imminent threat to the health of the present local population. However, there is a potential health risk for those frequenting the identified sites (e.g., the Monte de San Nicolás tailings, Filtros tailings, Plaza Ranas and the Old Tunnel), which bear mean surface concentrations near the U.S. EPA "inhalation reference concentration" of $300 \mathrm{ng} \mathrm{m}^{-3}$ (defined as a daily inhalation exposure of the human population that is likely to be without an appreciable risk of deleterious effects during a lifetime). On a cautionary note, a health study is highly recommended to confirm whether communities at risk have been impacted. Our follow-up work will include mercury speciation in tailings or sediments from select sites. 